\title{
Desperately Seeking Understanding: A New Perspective on Multiculturalism
}

\author{
Yelena V. Muzykina \\ Qazaq Research Institute for Futures Studies
}

\begin{abstract}
This paper proposes a discussion of the Muslim presence in modern Western Europe and the trends that accompany it. The author argues that such debates could not be conducted in the absence of Muslims themselves and introduces Ziauddin Sardar (a modern British Muslim intellectual) and his thinking on "multiculturalism". Sardar's vision on the matter radically differs from the traditional interpretations, which usually involve European Union policies regarding ethnic minorities. Sardar's theory is built on a broader context and develops such concepts as "diversity", “identity", and "power". His approach transcends the boundaries of a limited geographic area and could be applied to non-Western regions. The author attempts to apply it to Kazakhstan, in an attempt to see how it could work in the Kazakh sociocultural context. The main focus is on the ethnic and religious characteristics of the Republic. Finally, the paper contains some suggestions for the further development of Sardar's theory of multiculturalism. The conclusions offer a justification of the possibility and necessity to transform the idea of "multiculturalism" into "interculturalism".
\end{abstract}

\section{Keywords}

Ziauddin Sardar; multiculturalism; Kazakhstan; interculturalism

\section{Introduction}

The contemporary world requires a new understanding because the traditional notions and tools have mostly lost their meaning. The reality around us is becoming increasingly complex. On the one hand, material forms of human activity take on a planetary character; economy and politics surpass national borders, increasing the drift toward transnational associations and corporations. On the other hand, in the field of ideas, the trend goes in the opposite direction; nations become more and more divided along ethnic, religious, or cultural lines, rejecting universalistic utopias and turning to their own historical "roots". Economic globalism and political integration are confronted by cultural separatism, which becomes critical when we come to specific issues swamping Western Europe.

\footnotetext{
* Yelena V. Muzykina, Qazaq Research Institute for Futures Studies, Narxoz Business School, Almaty, Kazakhstan; m_yelena73@mail.ru.
} 
One of the issues is the growing presence of Muslims in the European Union (EU). The Summer School on Nationalism, Religion, and Violence in Europe (conducted in Prague between June 18 and 29, 2018) illustrated some concerns about the situation through different presentations and remarkable questions that the participants directed to the speakers. At the same time, the sessions demonstrated only one side of a contentious question. The efforts of modern Muslim scholars to defuse the situation were not brought in.

This paper has two primary objectives. The first one is to introduce some ideas that Western Muslim thinkers have developed to relieve the tension that clouds the sociocultural horizon of the Western world. These concepts could help to understand not only the political surface but the deeper personal level that underlines the whole context. The paper is limited to the views of Ziauddin Sardar, a modern Muslim scholar who lives and works in the United Kingdom (UK). Out of the vast number of topics that he considers in his works, I choose to tackle the issue of generating a peaceful multicultural society for respectful coexistence.

The second objective is to draw some lessons from the statistics, empirical facts, and theoretical materials related to multiculturalism and debates around the topic. The paper, first, presents the contemporary situation that has been formed in the countries of the EU in recent years. Secondly, it offers an overview of Sardar's theory of multiculturalism as well as his critique of multiculturalism as developed by Western policymakers and institutions. Finally, the applicability of Sardar's ideas to the reality other than the Western European context is considered. For this purpose, I bring in the example of Kazakhstan to examine the validity of the theorist's suggestions.

\section{Understanding What Went Wrong with Europe}

The second half of the 20th century marked a turning point in the development of relationships between the West and the Muslim world. During that time, Islam left its traditional geographic boundaries and entered Western Europe and North America, thus triggering the formation of a new cultural world order. Starting in the 1960s, Islam has paved the path for its presence in the social and political space of Western Europe; and the first decade of the 21st century indicates that it has settled quite confidently there. Today, more than 24 million Muslims live in the EU, comprising almost $5 \%$ of the population in 2016. They represent the most significant religious minority group among Europeans and the largest Muslim diaspora in the world (Hackett 2017). Among 28 members of the EU, six countries have the biggest Muslim population (Table 1) (Hackett 2017). 
Table 1: European countries with the biggest Muslim population

\begin{tabular}{|l|c|c|}
\hline Country & Estimated size in 2016 & \% of the populations \\
\hline France & $5,720,000$ & 8.8 \\
\hline Germany & $4,950,000$ & 6.1 \\
\hline The UK & $4,130,000$ & 6.3 \\
\hline Italy & $2,870,000$ & 4.8 \\
\hline The Netherlands & $1,210,000$ & 7.1 \\
\hline Spain & $1,180,000$ & 2.6 \\
\hline
\end{tabular}

The growth of Muslim population in Western Europe was a result of the sociopolitical developments rooted in the 1960s, when a surge in immigration brought thousands of migrants from the Maghreb countries, North Africa, and the Indian subcontinent, as well as from Turkey, to Europe. Each hosting country received a separate category of immigrants, which had formed due to specific circumstances. People from Turkey and the countries of the former Yugoslavia went to Germany, Moroccans went to Spain, and the UK was the destination for people from former British colonies in South Asia (India, Pakistan, and Bangladesh) and Africa (South Africa, Nigeria, and Ghana). Many from North Africa, namely, from Morocco, Algeria, and Tunisia, as well as from the former Southern Sahara colonies, rushed to France. This country, with the most significant number of Muslims, constitutes a separate case because its immigrant population grew up not only because of the immigrants seeking work after World War II; after the end of the Algerian War of Independence (1954-1962), hundreds of thousands of Algerians who fought on the side of France were granted asylum. The Muslim population has since expanded through legal birthrights, illegal entrants, and cases in which family reunifications were allowed (McCloud 2003, 166). In general, the overwhelming majority of the newly arrived were unqualified workers who got hired as laborers for low-paid work.

At the beginning of the process, Europeans and "newcomers" alike considered the move as a temporary trend. The Turks, Pakistanis, and Maghrebians expected to return home upon the completion of contracts, with enough money to support their families (Amghar 2007, 2). Therefore, European governments hardly thought of developing special programs related to Islam and the Muslim communities that lived on their territories.

However, since the mid-1980s, Muslim settlers have been less likely to consider returning to their homelands. On the contrary, once they have settled in new territories, they begin an active process of "reunion" with the families 
they had left behind. The children of immigrants attend European schools and universities, and visible signs of the "Other" culture's presence began to appear in the public space of Western Europe. The most striking expression of this process was the construction of mosques, which were virtually absent in European urban architecture until the 1970s. By the end of the 1990s, their number grew up to 6,000 ; the process was initiated by the first generation of migrants (Cesari 2006, 137).

As the second generation of immigrants grew up, the process of "Europeanization" of Islam began. Born and educated in West European countries, this new stratum, however, consisted of practicing Muslims who honored and followed the foundations of their religion and culture. They had already begun losing ties with the countries of their origin, increasingly perceiving themselves as French, German, British, or Belgian. This paradigm shift coincided with the movement that Muslims launched to acquire equal rights with their fellow citizens of European origin. Protests against all forms of discrimination - ethnic, racial, and religious - marked the struggle for civil equality. In 1983, for instance, a million-strong march - organized by SOS Racism -took place in Paris; the majority of the protestors were Muslims (Singer 1998). They demanded full access to the political, economic, and social aspects of life in their new homeland, including equal right to vote. These sentiments were quickly picked up by European Muslim organizations, which, on the one hand, supported the idea of developing bonds of young people with Islam, but, on the other hand, called the youth to consider themselves responsible citizens of their countries.

Such a turn made European politicians stop treating Islam as a "guest" entity that could just disappear at any moment with the return of immigrants to their homelands. They had to acknowledge that Islam had become an integral part of the political, cultural, and social life of Western Europe, being independent and viable. Regarding the third and the fourth generations of Muslims who were born and raised in the EU, it should be stated that they are not only legal citizens of the UK, Belgium, or Italy, but they were raised with and within European values. However, they maintain adherence to Muslim culture including its religious component.

Such a mix of seemingly conflicting values - European secularism and Islam - appears quite viable for Muslims who have formed different trends in perceiving and practicing Islamic norms in the new context. For example, research has identified, among Muslims, neo-fundamentalists, traditionalists, and adherents of the so-called "individual Islam" and "secular Islam" (Novikova 2008). Once again, the gradation of the new European Muslim 
groups is based on the degree of adaptation and commitment to European values.

The ordinary Western European's reaction to the permanent presence of Muslims in their societies reveals a different spirit. On the one hand, it looks like they have learned to live with the new members of their communities peacefully. In general, Western Europeans demonstrate acceptance of Muslims as their fellow citizens, and even as members of their families, as evidenced by a series of surveys conducted by the Pew Research Center between 2015 and 2017 in 34 Western, Central, and Eastern European countries ("Eastern and Western Europeans Differ $1 / 4$ " 2018). More than a half of Western members of the EU say they would accept a Muslim into their family. The percentage of those who say so in the top five EU countries with the biggest Muslim population varies between $60 \%$ and $90 \%$ (Table 2).

Table 2. Would you be willing to accept Muslims as members of your family?

\begin{tabular}{|l|c|}
\hline Country & \% of the population \\
\hline France & 66 \\
\hline Germany & 55 \\
\hline The UK & 53 \\
\hline Italy & 43 \\
\hline The Netherlands & 88 \\
\hline Spain & 74 \\
\hline
\end{tabular}

The Netherlands is among the top five most tolerant EU countries on the matter. The other four are Norway (82\%), Denmark (81\%), Sweden (80\%), and Belgium (77\%).

Moreover, Western Europeans are very likely to accept Muslims in their neighborhoods (Table 3) (Question: "Would you be willing...” 2018).

Table 3. Would you be willing to accept Muslims as neighbors?

\begin{tabular}{|l|c|}
\hline Country & \% of the population \\
\hline France & 85 \\
\hline Germany & 77 \\
\hline The UK & 78 \\
\hline Italy & 43 \\
\hline The Netherlands & 96 \\
\hline Spain & 86 \\
\hline
\end{tabular}


Similarly, again, in addition to the mentioned above Netherlands, the top five most tolerant countries toward Muslim neighborhoods include Norway (92\%), Denmark (91\%), Belgium (91\%), and Sweden (90\%).

Nevertheless, this idyllic picture is spoiled by the stances of the far-right movements that align with those populists who "warn" voters in Western Europe and North America about "migrants taking your jobs, Muslims threatening your culture and security" (Shuster 2016). Those parties have been making gains across Western Europe for several years and have reached their pinnacle with the refugee crises in the summer of 2015, when more than a million refugees from the Muslim world war zones came streaming to Western Europe in search of asylum. The popularity of the right-wing parties could be explained by the fundamental sociocultural changes in Western Europe: Western Europe was once nearly entirely white and Christian, but now, it has absorbed large numbers of Muslim immigrants from the Middle East and North Africa. The "rightness" of these parties is very European in a sense because "they tend to be nationalistic, favoring promotion of Christian values and strict limits on immigration, but also support a strong welfare state for native Europeans" (The Week 2015).

The situation is complicated by the fact that beginning with 2004, the composition of the EU has changed, spreading significantly from its historic Western part into Central and Eastern Europe. The latter seems less open and receptive to cultural and religious pluralism than is Western Europe. Some reasons could be traced back to the historical and political heritage of Central and Eastern Europeans, e.g., the Iron Curtain legacy. It includes uniformity in thinking, restrictions, and rigidity in all public spheres, as well as hostility to anything that falls out of standardized rules. They have formed, for decades, the mindset of those who joined the EU after the fall of the dividing barrier. It looks like a new version of the Iron Curtain is in the formation process, but now it is not between the East and the West: it is an "intra-EU" divider initiated by fierce debates among European leaders and policymakers about border policies and national values.

The most notorious voice of opposition to the EU's policy of professing "European values" belongs to Hungarian Prime Minister Viktor Orbán. In July 2018, he said that "Central Europe possesses a 'special culture,' one that is different from Western Europe" and that "every European country has the right to defend its Christian culture, and the right to reject the ideology of multiculturalism" (Ruse 2018). The Hungarian leader demonstrates his ongoing efforts to repel what he perceives as an "Islamic invasion of what used to be a Christian continent" (Ruse 2018). Addressing the Hungarian 
Parliament in May 2018, Orbán criticized the EU stance on migration: "In Brussels now, thousands of paid activists, bureaucrats and politicians work in the direction that migration should be considered a human right. 1/4 That's why they want to take away from us the right to decide with whom we want to live" (Santora and Bienvenu 2018).

Such declarations bring worries not only to EU leaders because the stances undermine the political unity of the EU. They trouble many ordinary citizens of the EU as well, among whom many are Muslims. This group of Western Europeans realizes that the issue of tolerance takes a new turn, bringing them a gut feeling of becoming political and ideological targets. That is why they raise their voices, first of all, via the Muslin public intellectuals, always sensitive to such changes. As insiders of both Western and Muslim cultures, the new generation of European Muslim thinkers recognizes the urgent need to be part of the ideological and theoretical debates on the issue of a new model of coexistence in contemporary society. For them, the end of the cultural hegemony of the West is apparent, and Islam has become an integral part of the Western landscape. They are sure that the universal nature of Islam - as its adherents proclaim - could contribute to the improvement of the wellestablished institutions of the EU.

So, let us now review some ideas on the matter of existence in a complex and multiple society, which have been expressed by one of these prominent European Muslim intellectuals, Ziauddin Sardar.

\section{Understanding Multiculturalism from a Different Perspective}

Trying to solve the sociocultural dilemma that the Western World encountered when a flow of Muslim immigrants reached its territories, Western governments kept working within a traditional Eurocentric framework. While unprepared to manage cross-cultural problems and often unfamiliar with Islam, policymakers developed a seemingly universal concept called "multiculturalism". A lot has been written to support or criticize it, including such books as Multiculturalism: Roots and Realities, by James C. Trotman (2002); Multiculturalism: A Civic Idea, by Tariq Modood (2013); Rethinking Multiculturalism: Cultural Diversity and Political Theory, by Bhikhu C. Parekh (2002); On Genetic Interests: Family, Ethnicity, and Humanity in an Age of Mass Migration, by Frank Kemp Salter (2007); Islam and Tolerance in Wider Europe, by Pamela Kilpadi (2007); Diversity in Europe: Dilemmas of Differential Treatment in Theory and Practice, by Gideon Calder and Emanuela Ceva Abingdon (2014), to name just a few. 
After a few years of implementing the multicultural approach, the Chancellor of Germany, Angela Merkel, declared it a failure in October 2010 (The British Broadcasting Corporation [BBC] 2010). David Cameron, the UK Prime Minister, soon echoed her. However, the idea keeps living in sociology and political philosophy, attracting attention and proving its viability. Yet, it is necessary to redefine multiculturalism from a broader perspective to escape a narrow-minded Eurocentric prospect. That is why it is important to consider the theory offered by Ziauddin Sardar, a British Muslim intellectual, whom The Independent called “the Britain's own polymath” (Kane 2002).

Highly critical of multiculturalism in its Western interpretation, Sardar (2003) presents his own vision of the notion in the essay Managing Diversity: Identity and Rights in Multicultural Europe (Sardar 2006), which we are going to consider in detail.

First, Sardar makes diversity a cornerstone of his new version of multiculturalism. He says that the presence of diversity in our life is inevitable. For him,

Every nation, every community, and every individual on the planet has to come to terms with diversity: the diversity of human communities, the diversity of different ways of being and doing, the diversity of contemporary identities, and the rich diversity of our flora and fauna. Living together in proverbial peace and harmony requires us to acknowledge, appreciate and support diversity; and create space for difference to exist as difference. Diversity thus challenges the very essence of our humanity, while enriching the sheer variety of different ways of being human (Sardar 2006, 270).

People have to recognize, learn, appreciate and maintain existing diversity. Starting from nature, flora, and fauna, humans have to learn to discern the positive elements of being different. Sardar suggests that deconstructing any human society, we can discover its multilayered nature. In the social context, it means that citizens should be considered not only as individuals but also as members of various entities, whether religious, ethnic, cultural, or regional. Such an approach helps to recognize the intricate pattern of relations that human beings have with each other. Therefore, the first lesson to learn is about an urgent need faced by European nations to develop a "cohesive set of values with due regard for diversity", which should be accompanied by discovering ways of nurturing that phenomenon (Sardar 2006, 270-271).

Someone might argue that this approach could complicate an already highly complicated agenda on the subject of "identity". Frequently, identity is treated as something used to meet challenges at home and abroad. Sardar ties identity to diversity, enriching the relationships between them through a human ability 
and a right to choose: first, multiple identities; secondly, alternative identities; and thirdly, prioritization of various identities. Such a position distinguishes Sardar from the traditional philosophical view that holds identity to be singular and discovered through interactions within a community. According to the traditional idea, people are "predestined" to their identity and there could be no discussion on the matter.

Further, Sardar's thought takes yet another turn, which, however, fits quite well with the diversity he advocates. He worries not about human ability to make a random choice of identity, but about the presence of different choices, alternatives, and variations that should be at our disposal simultaneously. Again, humans have to learn to manage the difference: "It is because we have a problem with pluralistic identities that we are in the midst of a global epidemic of the identity crisis. The symptoms of this crisis are everywhere." (Sardar 2006, 271)

In addition to our inability to manage multiple identities, we are seized with another challenge. It is a rapidly changing reality that ejects habitual notions, rendering the sources of our identity meaningless. Sardar brings up "Englishness" as an example (Sardar 2006, 272). The territory that could claim this term historically as its attribute presents now a heterogeneous and a multiethnic society. Much of the tradition associated with "Englishness" has become questionable and empty to the vast majority of those who inhabit England now. Sometimes, this term could sound even threatening. It is just one of the radical examples that humanity has to adjust itself to. "Thus, identity has become a perilous notion; and with it, diversity itself has become deeply perplexing" (Sardar 2006, 273). Therefore, the second lesson to learn from the Muslim intellectual is about the necessity to manage identity not as a "karma" but as an integral human right to choose; moreover, identity could be multiple and unique.

Then, how to reach that understanding and what needs to be changed? Answering these questions, Sardar points to the roots of the problem, grounded in the exclusive position of European identity as an indicator of all the others. The exclusiveness is based on a common past and cultural heritage, both of which, when checked against historical facts, turn out to be fabricated. For example, Sardar argues that

Europe has conventionally thought Islam to be an external Other. Muslims, in their turn, have always assumed that Europe had nothing to do with them. Yet, Islam and Europe have been intrinsically linked. Quite simply, there would be no Europe as we know it today without Islam. And Islam without Europe is unimaginable. It is not just that the two civilizations have shaped each other's identities in relation to 
each other - by defining the Other as the darker side of itself; but the interaction between the two cultures and civilizations also shaped their values and outlooks and hence their identities (Sardar 2006, 275).

Therefore, the next lesson to learn is quite severe. History is a tricky thing and could be easily fabricated. Sometimes, it happens unwittingly, but more often, it is done intentionally to reinforce the status quo, excluding any change and, thereby, any diversity from the picture. Following this path leads to civilizational degradation because self-indulgence masks inevitable historical collapse. That is why Sardar points out to the essential need for Europe to acknowledge its Islamic heritage and thus be true to itself and its history: "it would be initiating a reconciliation transcending all those past and present tensions that divide Europeans and Muslims" (Sardar 2006, 276). However, European Muslims have to do the same about Europe's share in their Islamic legacy and recognize that European values do not have much difference from those of the classical period of Islam. The heritage reconciliation adds more openness and inclusiveness to Muslim and European identities, laying the foundation of genuine multiculturalism.

Finally, after laying the foundation of diversity and building the walls of identity, Sardar starts the discussion of multiculturalism itself. $\mathrm{He}$ is not satisfied with a conventional definition of it as "the recognition that societies are pluralistic and consist of distinct cultures, multiple identities, and different ethnic components" (Sardar 2006, 276). What annoys him is the undue emphasis on difference and ethnicity. The intellectual asserts that multiculturalism should not be a "one-way traffic" offered by the white community to ethnic minorities. In the light of the quantitative growth of ethnic groups in Western society in recent decades, this suggestion sounds more than reasonable.

Sardar's vision of multiculturalism is based on the diversity of the European societies and incorporates two specific characteristics. The first one relates to the issue of power. The curtain of equality and the law, theoretically color blind, often hides an intention to keep nonwhite ethnicities in their place. Instead of that spurious parity, Sardar points out that different citizens have different needs and equal treatment requires that a full account of their differences are taken into consideration. Otherwise, if equality is ignored and uniformity is promoted, the latter turns into injustice and inequality.

The second feature of multiculturalism is about the transformation that has a critical nature and puts an end of the opposition "us" versus "them". As Sardar says, "Multiculturalism does not require more commitment to liberal values in Western societies, as some have argued. Rather, it requires a 
transformation of liberal values to more inclusive forms" (Sardar 2006, 281). The idea of transformation is very important for Sardar because it helps to move from a simplistic notion of multiculturalism as a tolerated extension of the Western version of liberalism to a more sophisticated process of transcending and transforming liberalism itself and to recognize it as a part of all traditions, groups, and communities. "And we have to realize", concludes Sardar, "that multiculturalism is a partner project - it requires full and equal partnership with other cultures in shaping modernity, postmodernity and the human future" (Sardar 2006, 282). This is the fourth lesson to learn from the discourse of the British Muslim polymath on the matter.

Thereby, Sardar approaches the concept of multiculturalism from within the Western European cultural diversity that he takes for granted. For him, it is not multiculturalism that serves as a framework for constructing different communities according to their cultural, ethnic, or religious varieties. The process works the other way around: the numerous communities are recognized for the sake of shaping multiculturalism properly. Sardar identifies that the primary objective for Europeans states is to "create space for difference to exist as difference; and for diverse communities to exist within their own parameters" (Sardar 2006, 285).

We should pay tribute to the unique position of Sardar in the discussion of multiculturalism, which helps him identify the most critical - and sometimes most sensitive - points. On the one hand, as an insider of the Western world, Sardar recognizes that the issue of power should be tackled in a specific way. Ignoring it leads to a false notion of plurality, which is usually expressed in different cuisines, fashions, and holidays. Instead, the marginalized should be brought into the circle of power; they have to receive rights to share power equitably with the "privileged" communities. Sardar points out that "giving diversity its due would require affirmative policies for certain minorities and recognition of collective and group rights" (Sardar 2006, 286).

On the other hand, as an insider of the Muslim world, he recognizes that the issue of identity could turn into a stumbling block within the framework of multiculturalism. That is why Sardar, recognizing a historical role of identity, does not consider it a fixed or limited entity. He appreciates the changing and flexible nature of identity. Sardar says, "Identity is not what we buy, or what we choose, or what we impose on others; rather, it is something from which we learn how to live, discover what is worth pursuing, and appreciate what it is to be different" (Sardar 2006, 286). In other words, exclusivist ideas, whether about culture, identity, truth, or ideology, should be abandoned in a plural society because they cannot lead to viable, multicultural Europe. 
The theory of multiculturalism that Ziauddin Sardar has presented in his essay Managing Diversity could find its applicability not only in European states. The issues of diversity, identity, and multiculturalism have become universal and worry non-European countries that also go through pains of developing their internal policies on cultural, religious, and ethnic dialogues. Let us take Kazakhstan as an example to try to understand how Sardar's theory could work in this Central Asian country.

\section{Understanding Kazakhstan's Multiculturalism}

A few factors could be identified in the contemporary sociopolitical life of Kazakhstan, making Sardar's theory of multiculturalism applicable to this region. Insofar as the primary concern of the concept relates to the interaction among ethnic, cultural, and religious components of a society, they are going to be under our primary consideration and critique.

The Republic of Kazakhstan is a transcontinental state located in the northern part of Central Asia, extending to some eastern territories of Europe. The very geographical disposition assumes the presence of different ethnic groups in Kazakhstan. Furthermore, the proximity to the renowned Silk Road, an ancient network of trade routes that connected the East and the West, made its tribute to the ethnic variety of the country. The more recent history of the region added to the multicultural picture of Kazakhstan. In the 1930s, it served as the place of deportation for different "unwanted" ethnic groups (the Tatars, Koreans, Germans, and Meskhetian Turks) whom Stalin's regime considered political opponents, while during World War II, Kazakhstan became a destination point for many people evacuated from the front lines of the war zone.

Thus, we can say that multiculturalism is a natural state of Kazakhstan, with its own long and rich historical heritage that is in contrast with the relatively recent developments in Western and Eastern Europe. Even a few decades of Kazakhstan independence have not changed the general picture, despite some increase of migration waves from Kazakhstan to other countries (Kazantseva 2018). While the Kazakhs comprise the largest ethnic group (63.1\%), there are $>120$ other ethnicities. Among them, the largest are Russians (23.7\%), Uzbeks (2.9\%), Ukrainians (2.1\%), Uygurs (1.4\%), Tatars (1.3\%), and Germans (1.1\%) (Kazakhstan Population 2018). They preserve their linguistic, historical, and cultural values. Some sociopolitical structures, created as consultation bodies, promote intercultural and multiethnic cooperation and stability in the Republic. The most prominent is the Assembly of People of Kazakhstan, which plays an important role in the formation of a unique model of social unity 
(The Assembly of People of Kazakhstan 2018). Its effectiveness and political independence could be debated, but the organization makes a difference in the society and contributes to the creation of necessary conditions for the development of cultures, languages, and traditions of all ethnic groups in the country.

Therefore, the ethnic composition does not constitute a problem within multiculturalism. The real issue arises when a close look is given to cultural and religious factors. The intimate interaction between culture and religion is well known. However, very often, one is taken for the other. In the case of Kazakhstan, the situation is even more complicated. The period of independence had to face the collapse of the old norms and values, as well as the quest for those sociocultural components that proved that the stability of these two factors had started. Unfortunately, the overall picture of Kazakh mentality and its structure has to be researched. At the same time, some status positions of religion in Kazakhstan society can be identified now. Let us concentrate on those that could influence the multicultural perception of people.

The most distinctive status of religion in Kazakhstan is its ethnocultural status. The conclusion is based on a number of findings from the research works conducted recently. The Friedrich Ebert Foundation in Central Asia conducted a study among the youth of the Republic in 2014 (Youth in Central Asia 2016, 114). Answering the question "What is your religion?" the participants gave the following options (Table 4):

Table 4: What is your religion (by ethnicity)?

\begin{tabular}{|l|c|c|}
\hline Response & Kazakh & Russian \\
\hline Islam & 96.9 & 2.3 \\
\hline Orthodox Christianity & 1.1 & 92.9 \\
\hline Catholicism & - & 0.6 \\
\hline I'm an atheist & 1.1 & 3.2 \\
\hline No response & 0.2 & 0.3 \\
\hline Don't know & 0.8 & 0.6 \\
\hline
\end{tabular}

The researchers confirm that the overall picture of the youth mirrors the situation among adults. Consequently, the ethnocultural status of religion demonstrates that people hold a close link between religious and ethnic adherence. The majority of Kazakhstan citizens accept faith as an ancestral heritage that reflects the historical development of the people and the nation. 
This specific status of religion can somehow explain the relatively negative attitude of the people to phenomena such as religious conversions, which have been developing in the country over the previous few decades. The results of the first research on religious conversion trends in Kazakhstan conducted by scientists at the Institute of Philosophy, Political Sciences and Religious Studies of the Committee of Science of the Ministry of Education and Science of the Republic of Kazakhstan identified a lack of tolerance among the people in the context of the personal decisions of close relatives or family members in terms of changing their religious affiliation (Table 5) (Bizhanov 2017, 279):

Table 5: Question: "If your relatives decide or have decided already to change their religion, how would you react to it?"

\begin{tabular}{|l|l|}
\hline Answers & $\mathbf{\%}$ \\
\hline I will be against that because we must hold on to the ancestral faith & 45.8 \\
\hline $\begin{array}{l}\text { I will not object because every person has a } \\
\text { right for freedom of conscience }\end{array}$ & 27.4 \\
\hline I will be indifferent to that decision & 17.3 \\
\hline $\begin{array}{l}\text { I will accept that decision with understanding } \\
\text { because I have changed my own affliation }\end{array}$ & 3.9 \\
\hline I do not know & 5.6 \\
\hline
\end{tabular}

The paradox of the situation is in the shallow level of the practical expression of the religious affinity of people in Kazakhstan. According to different results, from 6.5\% (Youth in Central Asia, 110) to $11.7 \%$ (Bizhanov, 156) of those who call themselves "believers" take part in the activities of their religious community, follow all religious precepts, and know the fundamental beliefs of their denomination. It means that the identity quest has arrived at the religious destination without understanding its obligations, thereby breeding cultural stereotypes. Culture and religion got completely mixed.

Moreover, the situation is generated and encouraged by governmental actions. According to foreign experts, "Before its 2011 religion law was enacted, Kazakhstan was one of the least repressive post-Soviet Central Asian states with regard to freedom of religion or belief" (Kazakhstan 2018). However, after enacting the law's registration requirements, the total number of registered religious groups fell sharply from 48 to 16 , especially among "nontraditional" religious groups. Though officially all denominations are equal under the religion law, the division into the so-called "traditional" (the Hanafi Islam and Orthodox Christianity) and "untraditional" (the "Others") religions is widely propagated by the state organizations and the religious bodies affiliated with them. 
Such ideology contributes not to the flourishing of multicultural ideas but to the tension that arises around the conversion phenomenon and identity problems. The issue of power that concerns Sardar is undeniable here. Tending to control the nonmaterial sphere of its citizens and dictating them on what to believe and how to do that, the government drops out its secular nature and abandons the principle of separation of the state and religion. According to Sardar's theory of multiculturalism, instead of semiofficially depriving religious minorities of any power, the state has to share that power, giving people the freedom to decide and choose what to believe. The change of religious affiliation is not a "high treason" or betrayal of ethnic culture. Someone can be a Kazakh Protestant or Russian Buddhist and still retain cultural traditions, appropriate rituals, and family ties. Moreover, an attempt to control the spiritual realm of its citizens is not a prerogative of a democratic state and sounds archaic.

Following the general concept of Sardar's theory of multiculturalism, whether we are talking about a difference in the field of religions or personal identities, the main conclusion is about the respective contribution of a broader variety to a holistic picture of society. Again, differences should be encouraged and celebrated, and space - judicial and educational - should be created for this purpose.

\section{Conclusion}

Making final statements, let us answer the question, "Why is seeking understanding so important in our contemporary world?" To start with, we have to agree that understanding is only possible within the process of continuous learning. Intellectual pride, which sees the bottom of its pit and has answers to all questions, has to turn into intellectual humility, which marvels at the boundless limits of knowledge and recognizes the validity of the Socratic maxim "I know that I know nothing". Therefore, the Quranic principle of diversity and plurality fits the picture, "O mankind, indeed We have created you from male and female and made you peoples and tribes that you may know one another" (Surah Al-Hujurat 49:13). This idea is so evident in Sardar's approach to multiculturalism, which cannot be overlooked. The principle is necessary for both humanity and the individuals within it because it helps to recognize the presence of a broader variety of opinions, traditions, and perspectives. The acknowledgment of mutual necessity is a part of the multiculturalism that Sardar wants us to understand.

Without this sort of understanding, we are almost condemned to cease the dialogue of cultures and civilizations and switch to a dictatorship and 
exclusivity. Understanding nurtures in us a permanent need in the Other as a necessary and integral part of our life. Like an artistic masterpiece consists of many different well-detailed objects that are easily distinguished but contribute to the perceptional integrity, so does the existential picture of collective humanity contribute to the same. It includes multiple diversities cultural, ethnic, and religious - but should be understood as an undividable unity.

However, I would like to go further and suggest that it is time now to recognize the need to move to the next stage and modify "Multiculturalism" into "Interculturalism". This transformation is inevitable considering those processes of interconnection, interrelations, interchange, and even interdependence, which develop intensively in the world. Moreover, such a change is imperative if we want to build peaceful existence in the future on the global level because multiculturalism keeps the West and the East separate, but interculturalism joins and merges them. I am not talking about an "updated version" of multiculturalism that Nasar Meer and Tariq Modood (2012) criticized in their paper, "How does Interculturalism Contrast with Multiculturalism?" The authors focused specifically on the political perspective and critically evaluated four ways in which conceptions of interculturalism positively contrast with multiculturalism. These are encouraging communication, recognition of dynamic identities, promoting unity, and challenging illiberality. After a detailed discussion of each factor, Meer and Modood conclude that "each of these qualities already feature [sic] (and are on occasion foundational) to multiculturalism too. Moreover, multiculturalism presently surpasses interculturalism as a political orientation that is able to recognise that social life consists of individuals and groups, and that both need to be provided for in the formal and informal distribution of powers, as well as reflected in an ethical conception of citizenship, and not just an instrumental one" (Meer \& Modood 2012, 192).

The interculturalism I propose goes beyond a matrix of central principles to contemporary liberal democracies (mostly Eurocentric) and includes Islamic, Confucian, Buddhist, Russian, Kazakh, and other indigenous epistemologies to form reality. This phenomenon offers genuine integration, the convergence of different cultural perspectives, terms, and concepts of different traditions. It paves a "middle way" at the junction of two extremes of multiculturalism: the first one is universalism, which superficially synthesizes different traditions within a framework of only one, namely, the Western tradition; the second extreme is dogmatic particularism, which denies the idea of compatibility of 
different cultures and their understanding for the perspective of the opponent tradition.

The development of interculturalism requires people who are educated in different cultures and can freely move from one to another (and Ziauddin Sardar fits very well into this category). Their worldview is formed under the influence of different traditions and can easily find appropriate reflective analogies in each of them. This process is going to form a new type of understanding that should become a phenomenon of the 21 st century.

\section{References}

Amghar, Samir, Amel Boubekeur, Michael Emerson, and Chris Allen. 2007. European Islam: the challenges for society and public policy. Brussels: Center for European Policy Studies.

Bizhanov, Akhan, ed. 2017. Religioznyye konversii v postsekulyarnom obshchestve (opyt fenomenologicheskoy rekoyestruktsii) [Religious Conversions in the Post-Secular Society (Experience of Phenomenological Reconstruction)]. Almaty: The Institute of Philosophy, Political and Religious Studies.

Calder, Gideon, and Emanuela Ceva. 2014. Diversity in Europe: dilemmas of differential treatment in theory and practice. Abingdon, Oxon: Routledge.

Cesari, Jocelyne. 2006. When Islam and democracy meet Muslims in Europe and in the United States. Houndmills: Palgrave Macmillan.

"Eastern and Western Europeans Differ on Importance of Religion, Views of Minorities, and Key Social Issues." 2018. Pew Research Center. October 29. http://www.pewforum. org/2018/10/29/eastern-and-western-europeans-differ-on-importance-of-religion-views-ofminorities-and-key-social-issues/

Hackett, Conrad. 2017. 5 facts about the Muslim population in Europe. November 29. http:// www.pewresearch.org/fact-tank/2017/11/29/5-facts-about-the-muslim-population-in-europel

Kane, Pat. 2002. “The A to Z of Postmodern Life, by Ziauddin Sardar." May 28. The Independent. https://www.independent.co.uk/arts-entertainment/books/reviews/the-a-to-z-ofpostmodern-life-by-ziauddin-sardar-5361451.html

"Kazakhstan." 2018. In Annual Report of the United States Commission on International Religious Freedom. Washington D.C.: U.S. Commission on International Religious Freedom, 180-185. https://www.uscirf.gov/sites/default/files/2018USCIRFAR.pdf

Kazakhstan Population. 2018. World Population Review. http://worldpopulationreview.com/ countries/kazakhstan-population/

Kazantseva, Ol'ga. 2018. Kto uezzhaet iz Kazakhstana: Pravda I Vymysel [Who goes away from Kazakhstan: Truth and Fiction]. Information-Analytical Center. July 19. https://iacentr.ru/experts/olga-kazantseva/kto-uezzhaet-iz-kazakhstana-pravda-i-vymysel-/

Kilpadi, Pamela. 2007. Islam and tolerance in wider Europe. Budapest, Hungary: International Policy Fellowships, Open Society Institute.

McCloud, Aminah Beverly, Scott W. Hibbard, and Laith Al-Saud. 2013. An introduction to Islam in the 21st century. Malden, MA: Wiley-Blackwell. 
Meer, Nasar \& Tariq Modood. 2012. "How does Interculturalism Contrast with

Multiculturalism?" Journal of Intercultural Studies. 33(2): 175-196.

"Merkel says German multicultural society has failed." 2010. BBC News. October 17. https://www.bbc.com/news/world-europe-11559451

Modood, Tariq. 2013. Multiculturalism: a civic idea. Cambridge: Polity.

Novikova, Ol'ga. 2008. "Islam v Evrope: puti adoptatsii k novym usloviyam” [Islam in Europe: the Ways to Adapt to New Conditions]. Aktual'nye Problemy Evropy, 1:188-213.

Parekh, Bhikhu C. 2000. Rethinking multiculturalism: cultural diversity and political theory. Cambridge: Harvard University Press.

Ruse, Austin. 2018. "Hungarian Leader Rallies Christians, Gives EU Elites Indigestion." August 02. C-Fam. https://c-fam.org/friday_fax/hungarian-leader-rallies-christians-gives-euelites-indigestion/

Salter, Frank Kemp. 2007. On Genetic Interests: Family, Ethnicity, and Humanity in an Age of Mass Migration. New Brunswick: Transaction Publ.

Santora, Marc and Bienvenu, Helene. 2018. Secure in Hungary, Orban Readies for Battle with Brussels. May 11. The New York Times. https://www.nytimes.com/2018/05/11/world/europe/hungary-victor-orban-immigration-europe.html

Sardar, Ziauddin. 2003. Islam, postmodernism and other futures: a Ziauddin Sardar readerl edit. by Sohail Inayatullah and Gail Boxwell. London; Sterling (Virginia): Pluto Press.

Sardar, Ziauddin. 2006. "Managing Diversity: Identity and Rights in Multicultural Europe." In How do you know? Reading Ziauddin Sardar on Islam, Science and Cultural Relations, edited by Ziauddin Sardar and Ehsan Masood, 270-287. London: Pluto Press.

Shuster, Simon. 2016. "European Politics Are Swinging to the Right." September 22. Time. http://time.com/4504010/europe-politics-swing-right/

Singer, Daniel. 1998. "France, Racism and the Left." The Nation. January 2. https://www. thenation.com/article/france-racism-and-left/

The Assembly of People of Kazakhstan. 2018. Official Site of the President of the Republic of Kazakhstan. Accessed December 30. http://www.akorda.kz/en/national_projects/theassembly-of-people-of-kazakhstan.

"The rise of Europe's far right." 2015. The Week. September 15. https://theweek.com/articles/576490/rise-europes-far-right

Trotman, James C. 2002. Multiculturalism roots and realities. Bloomington: Indiana University Press.

"Q. Would you be willing to accept Muslims as neighbors?" 2018. Pew Research Center. http:// www.pewforum.org/wp-content/uploads/sites/7/2018/10/East-West-Neighbors-tables.pdf

Youth in Central Asia: Kazakhstan. Based on sociological survey. 2016. Almaty, Friedrich Ebert Foundation Kazakhstan. 